\title{
Hughes, Cullen, and the In-sites of Loss Marisa Parham
}

By calling themselves to remember Africa and/or the racial past, Black Americans are actually remembering, as in repopulating broad continuities within the African diaspora. This movement is nonlinear, and it disrupts our notions of chronology... an investigation of Harlem as a northern urban community reveals direct - deliberate, crafted ties - to the American south and then to Africa. and these are not places but stages or sites on which the drama of self-acquisition is played.

- Melvin Dixon, “The Black Writer's Use of Memory"1

In “The Black Writer's Use of Memory," Melvin Dixon outlines rather nicely some of the ways African-American writers have employed sites of memory in their work. Such writers call on us to reconsider the psychic and physical spaces we inhabit and how we use those spaces to complete various senses of group or individual identity. Sites of memory validate identities by anchoring a group's or individual's historically paratactic experience within a structure of meaning, retroactively inscribing such subjects into referential, narratable places in space and time. Such feats are by nature acquisitive, constantly calling real and imagined pasts into the service of the present and enabling African Americans to, as Dixon puts it, "enlarge the frame of cultural reference for the depiction of black experiences by anchoring that experience in memory-a memory that ultimately rewrites history." 2

The term "site of memory" was popularized in the late eighties by the French historian Pierre Nora, who claims that lieux de mémoire have become necessary in the absence of milieux de mémoire, "real environments of memory."з In Nora's schema, a real environment of memory is characterized by a people's daily commitment to tradition, ritual, and the transmission of the past to each generation, which is to say that within a "real environment of memory" habitus is structured by the connection between contemporary practices of living and the pasts of those practices. The cultural efficacy of such an environment disappears, however, when a community becomes subject to the ruptures we have come to associate with modernity and can no longer locate its reason for being in the perpetuation of shared and culturally [429] supported pasts. It is in this sense that sites of memory are produced in response to specific needs and demands, 
coming into being through absence and literally placed in lieu of lost connections. Building on Dixon's aforementioned sense of African-American memory work as playing out on a series of sites or stages, I am interested in narratives of excavation, particularly how such narratives attempt simultaneous creations and reclamations of selves feared lost in transition. In this essay, I will examine how one poet, Langston Hughes, constructs a site of memory that trumps the ravages of time and space and at how his contemporary, Countee Cullen, critiques Hughes's strategy by foregrounding the limits inherent to such artifice. Each author, I believe, is caught up in the tide of social and cultural nation-building important to the Harlem Renaissance, and where each stands in relation to the question of the past's representation ultimately bears on each author's take on what it means to be an artist.

Even though Nora himself was mainly concerned with transformations in French society, particularly the diminishing status of the local in the face of mass culture, thinking about sites of memory offers us a way of thinking about how people might work through other kinds of unwanted or unexpected losses of community, a pervasive concern for anyone building identity in a diasporic context. ${ }^{4}$ It is important to understand, for instance, that the "re-membering" Dixon refers to grew more pervasive in a time of growing disillusionment, as many African Americans who arrived in Harlem found it difficult to reconcile the material reality of the place with the desires and imagination that had brought them there. By the end of World War I, Harlem had become a diasporic homeland for post-emancipation African Americans from all over the United States and the Caribbean; yet, even by the beginning of what would come to be known as the Harlem Renaissance, Harlem had already come to exceed itself as merely one of many New York neighborhoods, insofar as the Harlem Renaissance - a revolution in how black Americans thought about and talked about themselves - was in fact launching in a variety of northern cities, all of which were flooded with southern blacks looking for new lives. In this way the Harlem Renaissance was about much more than place per se, for in general black people's northward migration simultaneously signified other kinds of movements, movements, or perhaps more specifically moments, undergirded by transformations in ideas about how to be, by new senses of being that transcended mere spatiality. The Great Migration thus also signified moves from slavery to freedom, from illiteracy to the literary and informational, and from tradesmanship [430] and land tillage to industrialized work and professionalization. Overdetermined, the term "Harlem" had come, then, to signify everything the postemancipation United States was supposed to offer. It is in this way that the Harlem Renaissance was as much as anything about remaking oneself in time, over and against being in a specific place, an interchange often made possible through feats of memory.

Throughout African-American literature and culture we find repeated references to the "many thousands gone," a lamentation shaped in slavery and echoed even in the requisite libations performed in much contemporary African-American popular culture. Perhaps at first the gone were the families and communities left behind in Africa; maybe later they were the ones who never survived the Middle Passage or the ones who died in slavery. Maybe they were families, friends, lovers, and children separated 
on the auction block or relationships fragmented by the scatter-effect of the Great Migration. Maybe they were the ancestors sacrificed to the exigencies of racial passing or, later, the black neighborhoods stunted by the deepening pervasiveness of urban blight. Indeed, on the facts alone, it might be reasonable to theorize the AfricanAmerican community as one manifestly constituted through loss, losses that are often represented as migrations, as passages away. But, somehow, even as such a litany of unbearable losses carries more than a little something, it cannot carry everything. For even though "lamentation and mortification," as Karla Holloway puts it, have "both found their way into public and private representations of African America to an astonishing degree," with that tradition of loss also comes a tradition of "grace, hope, and resilience." 5 The losses may be unbearable, but, even sometimes paradoxically, they have been borne, and this despite the immense variety of physical and psychic violences put to making African arrivals in the New World as symbolically terrible as they were materially terminal. What we might come to realize, then, is that the term "migration" names a dialectic characterized at its poles by longing and innovation, by mourning and transformation. Becoming gone, in other words, is a process that transforms the lives of the people passing away and the lives of those who must come after. Every gone does not necessarily mean goodbye.

It is difficult to theorize migration's recoveries because it is difficult to imagine most kinds of afterlives, more so when we know that so many of the migrations forced and undertaken in the black diasporic experience have historically ended in death, terror, and destruction. But understanding recovery, understanding the fact that lives might again become livable after terrible events, is necessary to the interpretation [431] of any art growing out of such events. The fact of writing after Middle Passage is particularly compelling when considered in light of the ways in which that journey might also be read as a journey out of subjectivity itself: from person to slave, from African subject to American commodity. In 1789, Olaudah Equiano would recount his own such journey from subject to object. Facing outward, towards the sea and away from home:

The first object that saluted my eyes when I arrived on the coast was the sea, and a slave ship, which was then riding at anchor, and waiting for its cargo. These filled me with astonishment, that was soon converted into terror, which I am yet at a loss to describe, and much more the then feelings of my mind when I was carried on board. I was immediately handled and tossed up to see if I was sound. ${ }^{6}$

Standing at the threshold, Equiano sees the sea, which he describes as a "first object," adding "and a slave ship" as if the vessel were a mere accessory to the crucial first object, the site of the crime. Astonished by the alien ship, "waiting for its cargo," the newly enslaved African would not, even in retrospect, be able to find the language with which to express the quality of this terror. The "toss[ing]" in fact presupposes the absence of speaking, insofar as it presupposes the absence of personhood. Another captured African, Quobna Ottoba Cugoano, would write of his experience: 
[W] hen a vessel arrived to conduct us away to the ship, it was a most horrible scene; there was nothing to be heard but the rattling of chains, smacking of whips, and the groans and cries of our fellow-men.

Metonymic, Cugoano's narrative sinks into passive voice as the scene's full implication comes to his reader in chains of sound and signification. Both men's descriptions move away from first-person, intensifying their descriptions of an intense breaking away at the genesis of a new identification:

When I looked round the ship too [I] saw a multitude of Black people, of every description, chained together, every one of their countenances expressing dejection and sorrow, I no longer doubted of my fate.

Equiano's recognition of himself as the ship's cargo comes simultaneously with his recognition of other black people, people whom he, before this moment, would have had no reason to identify as black. Previously, if they were to at all be identifiable to him, it would have been through a series of other signifiers, through ethnicity, religion, [432] language, and so on. Nor would he have had reason even to identify with them. Racial difference, as it were, was not a difference that mattered before Equiano's recognition of his own position within a new structure of meaning; his recognition of himself as a slave comes suddenly and through a nascent cognition of such difference. Like the sly permeation of saltwater through a coetaneous boundary, it is an awareness that assails the sensational body, drawing the boundaries of its imprisonment with sight, sound, smell, and touch. Forced to identify with the "black people, of every description, chained together," Equiano is put at a loss in his own transfiguration from an active, desiring subject into the object of an abject sentence. When Equiano steps onto the vessel and becomes the cargo, he enters into his new identity as a slave. He writes, "[Q]uite overpowered with horror and anguish, I fell motionless on the deck, and fainted." 9

In neither Equiano's nor Cugoano's account is there a sense that any future could possibly follow those first moments of each man's enslavement. Their migrations are experienced as journeys into hell, and their stories narrativize processes of becoming one of the many thousands gone. Yet despite their descent into goneness, we also know that both men lived. Neither man would physically return to Africa, however, and the general absence of stories of return perhaps contributes to a historical sense of that first passage across the Atlantic Ocean as a movement across a critical and absolute boundary. Situated in both men's autobiographies as a state of freedom to which each slave must rightfully be returned, Africa becomes a figuration, a story of a stolen past told in the service of their political work as abolitionists. More than a century later, a young Hughes would travel the world by ship, eventually crossing the Atlantic and returning to Africa, where he hoped to recover this past. The return, however, was not so easy, as the kind of ontological and spiritual recovery he sought would require more than landing on the soil of a land that had in fact been passed down to him as a figure. Ultimately, his journey to Africa may have been less satisfying than an earlier literary 
attempt, a metaphorical passage made possible through his exploration of a site of memory.

\section{Flowing}

In the first volume of his autobiography, The Big Sea, Hughes recalls writing one of his best known poems, 1921's “The Negro Speaks of Rivers." The poem was written during a time of relative despair, when, despite having both parents, he thought of himself as an orphan. ${ }^{10}$ [433] This sense of alienation is especially evident in his relationship to his father, a man with whom Hughes could not imagine identifying. In his autobiography, Hughes repeatedly remarks on this distance, often linking it to his father's "strange dislike of his own people," a dislike contrary to the younger Hughes, who claimed to trace many of his own best memories to working alongside other black people, mostly migrants from the South: "They seemed to me," he writes, "like the gayest and the bravest people possible - these Negroes from the Southern ghettoes - facing tremendous odds, working and laughing and trying to get somewhere in the world." 11

When reading The Big Sea, and his later volume, I Wonder As I Wander, one cannot help but notice how Hughes spent much of his young-adult life in transit, which seems compelling in the life of a man whose artistic life work was so deeply invested in locking down the loci of African-American experience. Sitting on a train, on a journey to Mexico to meet his estranged father, Hughes has his first encounter with a site of memory, which he retells in the following way:

now it was just sunset, and we crossed the Mississippi, slowly, over a long bridge. I looked out the window of the Pullman at the great muddy river flowing down toward the heart of the south, and I began to think what that river, the old Mississippi, had meant to negroes in the past - how to be sold down the river was the worse fate that could overtake a slave in times of bondage. Then I remembered reading how Abraham Lincoln had made a trip down the Mississippi on a raft to New Orleans, and how he had seen slavery at its worst, and had decided within himself that it should be removed from American life. Then I began to think about other rivers in our past - the Congo, and the Niger, and the Nile in Africa - and the thought came to me: "I've known rivers," ... as the train gathered speed in the dusk, I had written this poem, which I called "The negro speaks of rivers." ${ }^{12}$

Historically, being "sold down the river" did not always have to mean that one would actually take a trip down the Mississippi, yet even today the phrase nonetheless evokes a sense of irrevocable passage. During slavery it meant a trip to the auction block; today it still connotes deep betrayal. As a site of memory, the Mississippi may as well evoke the Atlantic, perhaps even a cultural memory of water as metonym for loss and separation. ${ }^{13}$ But, in this passage, as soon as Hughes evokes the site's meaning, he immediately begins to recuperate it by pulling into his narrative the highly contested (though one would not think so here) story of Lincoln's journey down the Mississippi. By doing so, Hughes neutralizes the despair culturally attached to travel down the [434] Mississippi, thus making it so that his narrative can instead end with slavery being "removed from American life." So openly recuperative; there is a sense here that 
the Lincoln story cannot quite align the end of the reminiscence with its beginning. But, nonetheless reaffirmed, Hughes is now able to recall "other rivers in our past," African rivers, followed by the realization: "'I've known rivers.'“

Hughes stages his final realization as an epiphany, as a revelation that has come to him via a journey back into his own memory, a journey I think we are supposed to understand as back into the self. This journey, he tells us, inspired "The Negro Speaks of Rivers," in which he draws an important relationship between blood and water, visà-vis the figure of the river:

I've known rivers:

I've known rivers ancient as the world and older than the

flow of human blood in human veins. ${ }^{14}$

IAntecedent to human experience is the fact of the river, the flow of which is here represented as ahistorical and outside the passage of human time. In this stanza there is an implicit similarity between water and the "flow of human blood in human veins," and it is through the construction of this identity-potentiate that Hughes is able to articulate a mobile and fluid subject, an enunciative " $\mathrm{I}$ " who has become as ahistorical as water itself. Indeed, if we understand Hughes as the "I" of the first stanza, as well as the Negro of the title, we can think of this poem as the Negro knows, and is therefore authorized to speak of, can tell others about, rivers:

I bathed in the Euphrates when dawns were young.

I built my hut near the Congo and it lulled me to sleep.

I looked upon the Nile and raised pyramids above it.

I heard the singing of the Mississippi when Abe Lincoln

went down to New Orleans, and I've seen its muddy

bosom turn all golden in the sunset.

By positioning himself as the Negro of rivers, Hughes asserts his own timelessness as an experiential fact, particularly as this timelessness is made analogous to the lack of distance between the poem's geographical sites: read the river as blood, blood that flows across the landscape of time and space and through all Negroes. Within such a reading, the river signifies multiple I's that can be expressed as one. Such a reading also reveals the poem's heliocentric structure, as meaning radiates [435] outward from the central set of images of the various rivers. This set at once describes and enables the multiple subject, a historically active I that attests to witnessing itself in its own past $-I$ bathed, I built, I looked, I heard, I saw, I know - and thereby makes it appropriate for the poem to end with the moment of its own genesis. By returning the outer rings of its meaning to its center, the poem's structure becomes circular in three dimensions. Hughes watches the sun set over the Mississippi. 
In the poem's denouement, "[m]y soul" (13) stands as a universal soul that deepens with experience and also allows more than one way to read the poem's title. On the one hand, to speak is to say, to tell of or to something actively: the Negro is the speaking subject. To speak, however, can also be interpreted as an adjectival gesture: the Negro "speaks of," as in reminds one of, bespeaks, rivers. In this second sense, "Negro" becomes a metaphor for "rivers," which authorizes the assertion "My soul has grown deep like the rivers" (13), and thus allows the speaker to graft onto a black collectivity a historical soul herein made continuous with his own, no-longer-problematic identity. In the discursive space of the poem, this soul recalls each episode as it witnesses itself across boundaries of time, space, and the Middle Passage. In his creation of a site of memory Hughes displaces responsibility for transcendence of the thetic onto water and thus transforms a site of historical loss into one of recovery, while nevertheless still carrying a trace of its original negative signification. Ultimately, the historical accuracy of each image in the poem's central stanza may be irrelevant as the text establishes itself as a lieu de mémoire, referenced to the racialized body: "And these are not places but stages or sites on which the drama of self-acquisition is played."

In Revolution in Poetic Language, Julia Kristeva insists that "the thetic conditions the possibilities of truth specific to language: all transgressions of the thetic are a crossing of the boundary between true and false." ${ }^{15}$ If we understand the thetic as a term for a loss that cannot be recovered, in the sense that it is impossible for us to return to the world we occupied prior to desire, prior to language and the break that makes language possible, then to speak or write truthfully is to accept that limit: one only speaks of what one knows or sees, a constant and undying gesturing toward verisimilitude; anything else is only the product of an unselfaware imagination. The exception to this, however, lies in what Kristeva dubs "poetic language," a generative language that comes into being as a trace of an absence recognized or remembered vis-à-vis the semiotic. ${ }^{16}$ She goes on to add that [436]

[m]imesis, in our view, is a transgression of the thetic when truth is no longer a reference to an object that is identifiable outside of language; it refers instead to an object that can be constructed through the semiotic network but is nevertheless posited in the symbolic and is, from then on, always verisimilar. ${ }^{17}$

Even though Hughes's place-names of course refer to material places, as sites of memory, Hughes's rivers are posited firmly in the symbolic and do not in fact exist outside of language. They are real and true places insofar as they exist to the subject, but false as they are not verifiable outside of an interpretative act, an act made possible only by the absence of the places themselves; again, in lieu thereof. With this poem, Hughes attempts to replace a racial past characterized by loss by diverting attention from the fact of that loss, even though it is the loss itself that engendered the text-and it is in this sense that the poem's citation of its constitutive absence reveals a fundamentally elegiac strategy, despite the recuperative elation with which the poem ends. Transformative in its symbolic turn, for it is in fact not a return, "The Negro Speaks of Rivers" is fully self-referential and self-authorizing in its attempt to tell us the 
truth about African-American origins and the veracity of black identity. It subverts notions of linear temporality, instead relying on repetition to convey a sense of constant, active flow, as if after the ending, "My soul has grown deep like the rivers," the poem could regenerate itself. In this way, Hughes imbues water with agency and represents it as the embodiment of perfect memory. Maybe, with time, the specific images would change - but the text, or rather its sub-textual energy, will always remain, beautiful and nostalgic, able to recast a moment in its most generative, therapeutic light.

On the one hand, to establish a site of memory commensurate with one's own body seems an efficacious strategy for overcoming the losses inherent to forced migration. Yet in its effort to overcome historical rupture and fragmentation, "The Negro Speaks of Rivers" produces a potentially haunting ideality, for the image the poem reflects back to its reader may exceed the reader's capacity to in fact meet the image and thereby experience the promise it offers. Further, insofar as successful identification relies on social ratification, Hughes's consciously racialized, homogenous site proves materially inadequate. The African-American subject is by necessity a hybrid subject; for although there was not for Hughes a ratified identification with an ideal Americaness, for which we may hold responsible the racism of twentieth-century America, the fact of the Middle Passage nonetheless disallows an African American's identification as purely African. [437]

Years after writing “The Negro Speaks of Rivers," Hughes would record in The Big Sea an attempt to attend a religious ceremony with Pey, one of his African shipmates. Hughes feels rejected when Pey does not identify him as African: “'But I'm not a white man,'“ Hughes argues; "'You no black man, neither,' said Pey impatiently," thus rejecting Hughes's essentialized ideal of his own Africaness. 18 By doing so, by looking at Hughes and acknowledging difference, Pey exhumes the inescapability of the very thetic experience "Rivers" seeks to elide. Although he does not realize it, Pey removes the "African" from African-American and leaves Hughes with "-American": at a distance from American, not quite American, or simply a hyphen. ${ }^{19}$ Pey relegates him to an ambiguous, heterogeneous space from which Hughes cannot claim a single, ratified origin. As Hortense Spillers has suggested,

[t]hose African persons in 'middle Passage' were literally suspended in the "oceanic," if we think of the latter in its Freudian orientation as an analogy for undifferentiated identity: removed from the indigenous land and culture, and not-yet "American" either, these captive persons, without names that their captors would recognize, were in movement across the Atlantic, but they were also nowhere at all. ${ }^{20}$

Pey's abjection returns Hughes to nowhere at all as he adds to Hughes's understanding of heritage a tacit awareness of his genealogical distance from Africa. As Arnold Rampersad notes, Hughes "quickly discovered that no African thought of him as one of them: 'The Africans looked at me and would not believe I was a Negro.'“ ${ }_{21}$ His, or for that matter any post-Passage subject's, desire to return to a pure, single origin is reasonable in light of the privileged status given to genealogical homogeneity in the 
context of any national identity. But the sanctity of the rivers, insofar as it posits an immutable racial origin, is undergirded by a misrecognition. Although Hughes's water and blood metonym works in the interest of creating an unfragmented racial self, that same "blood" - genealogy - also reflects loss or, perhaps more precisely in this case, the truth of an heterogeneous, entangled origin, à la Hughes's own muddy Mississippi.

\title{
II. Dammed
}

In what Dixon refers to as "an enigma of cultural memory," Cullen's 1925 "Heritage" is everything "Rivers" is not.22 It is as ambiguous as Hughes's poem is certain, something murky and sensate to the sun of [438] Hughes's hot and hard self-affirmation. In "Heritage," one can never escape the absence of the thing itself, and here Cullen writes the lieu de mémoire as untenable. Soon after it begins, "Heritage" speaks its skepticism aloud:

\author{
Africa? \\ A book one thumbs \\ Listlessly, till slumber comes. \\ Unremembered are her bats \\ Circling through the night, her cats \\ Crouching in the river reeds, \\ Stalking gentle flesh that feeds \\ By the river brink. ... ${ }^{23}$
}

Here, the site of memory is self-consciously revealed as a site of artifice. This is captured in Cullen's figuration of Africa as a book, which, mindlessly perused, becomes the ultimate signifier of memory cut loose from its milieu, set adrift without context and without reference. The absence of an authentic site of reference makes unremembering possible, as the reader, or perhaps even the book's writer, actively chooses what to present. The imagery for what has been unremembered is sharp, dark, and quiet, as if the same river that brought Hughes a sense of comfort is for Cullen a place fraught with danger and ambivalence: there is no safety in Cullen's text. Further, if we continue the notion that sites of memory anchor experience, what becomes evident is that there is no anchor for a real body, for "gentle flesh," experiencing a real loss in the world, a loss that is not itself easily located.

As Dixon reads it, Cullen's poem "vacillates between acceptance and rejection of ancestry the speaker's ambivalence fails to affirm - even ironically - the complexity of a self discovered through the art of memory." ${ }_{24}$ But perhaps what Dixon identifies as a failure in Cullen's art is in fact the poem's organizing principle: this is a poem about the failure of art as compensation for reality, a failure that deepens the pain of remembering that one has unremembered something that one never knew. "Heritage" begins with a dilemma: 


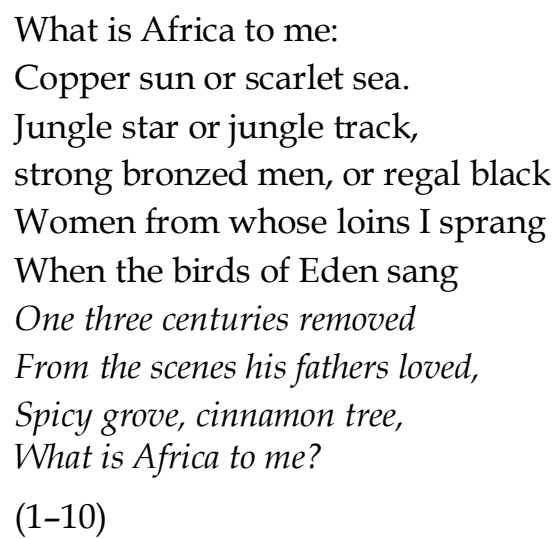

Where Dixon expects ironic self-reflection, Cullen offers tragedy, for even to write against the nostalgia of the constructed site of memory Cullen must use images gleaned from those very sites, a dilemma which is here played out as a problem of selection without knowledge: sun or sea, star or track, men or women. If "The Negro Speaks of Rivers," then, hearkens to the recovery of loss, "Heritage" moves inexorably towards the loss of loss. As recovery marks the emergence of the subject in Hughes's poem, in "Heritage" we instead find his dissolution.

The subject's dissolution is particularly compelling in light of what while reading the poem feels like the overwhelming presence of the speaker. The refrain, "What is Africa to me," has, by the end of the stanza, become "removed / From the scenes his fathers loved," with no ostensible transition from the first to third persons. This transition, from $m e$ to $I$ to his, and back to me again, makes suspicious the very notion of subjecthood. If one is removed from the scenes one's (fore)fathers loved, if one is detached from one's ancestry, what indeed does Africa as a site mean to the very notion of me-ness? What does this absence mean for one's very capacity for signification? And what, therefore, is the status of truth in the absence of reference? Is any utterance grounded in a lieu de mémoire necessarily untenable? The next stanza begins:

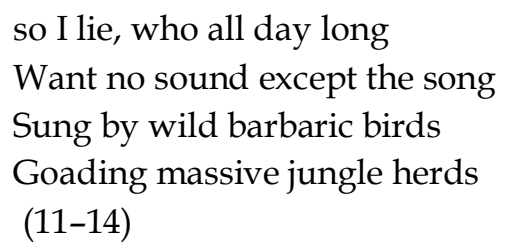

There are at least two possibilities of "lie": that he is lying, passive and immobilized by contradictory forces of presence and absence, and also that he is lying; he is not telling the truth. The act of lying is always characterized in this poem as an urgent response, strengthened here by Cullen's use of "[s]o," which generates causality between the poem's stanzas. Gerald Early notes that

[s]ome readers have criticized "Heritage" for not offering more realistic images of Africa, decrying Cullen's ignorance, but that is one of the many levels on which the poem [works], the narrator is lying. These images of Africa are lies; certainly Cullen knew that. but is the poem also lying when it suggests that Africa means nothing to the narrator? 
or is the poem lying when it suggests that African means anything to the narrator? or is this very interiorized speech-act, speech-event poem nothing more than the system of lies that the impotent Black intellectual uses to heal his own sickness of alienation and despair? ${ }^{25}$

Early is right to be suspicious, for is it not often the case that we suspect that a person claiming to have forgotten something is indeed lying? "I forgot" is different from "I never knew," for the former must compulsively offer up a trace of the supposedly disappeared. It must point to the site of the unremembered: "Something has gone missing, but I do not know how." Forgetting names a lost connection to a memory that may or may not still be present, and for this reason we might consider Cullen's lying as way of positing memory's limit as analogous to a limit in representation: the distance implicit in any formally ironic or allegorical gesture, the representation of one thing as another, the act of naming without naming; such strategies reflect the constitutive contradictions of a person realizing that he has lost memory of an experience that he has never had but, nonetheless, needs. In its own way, Cullen's poem does everything Dixon would like it to do, but with unexpected results.

In "Heritage," Cullen offers us a subject about to explode under the pressure of balancing memory and history, and this is mainly articulated as a split between mind and body. The mind knows its history of absences and displacements; the body, meanwhile, is wrought by "pulsing tides" of memory (26). Like "Rivers," Cullen's poem represents a deeply self-referential experience, crossing boundaries between true and false by referring to nothing outside of the narrator's word. There is no truth, but, and maybe more tragically, there is no false; he will not allow himself to be pulled into the book. However, unlike Hughes, whose poem disavows historical loss, Cullen interiorizes it, thus producing meaning through an incorporated contradiction, incorporated in the psychoanalytic sense, but also in the sense that Cullen makes the work of coping corporeal, leaving it to a body constituted by sensational acts of longing and un/remembering. In "Heritage," the narrator exists only as a tension between the history of himself in the world and what he experiences as his body's memory of something he has never known, a haunting affect.

In an essay entitled "The Site of Memory," Toni Morrison's notion of emotional memory speaks to this sense of remembering in the shadow of Passage:

\footnotetext{
you know, they straightened out the Mississippi river in places, to make room for houses and livable acreage. occasionally the river floods these places. "floods" is the word they use, but in fact it is not flooding; it is remembering. remembering where it used to be. all water has a perfect memory and is forever trying to get back where it was... It is emotional memory - what the nerves and the skin remember as well as how it appeared. ${ }^{26}$
}

Morrison begins her description with a disruption, the turning of the Mississippi River from its natural course. But because water has a perfect memory, because it cannot forget, it will always re-turn. Thus troped, Morrison's river offers her reader a kind of memory that operates on two distinct levels: as an image frozen in the mind's eye and as a sense that constitutes the body as a corporeal "I." 
Such linkage to the past, however, is far from easy and, once recognized, exacts a cost. We might remember here that when rivers flood, homes are destroyed and lives are lost or displaced. Indeed, in "The Rhetoric of Temporality," Paul de Man notes that

[w] hereas the symbol postulates the possibility of an identity or identification, allegory designates primarily a distance in relation to its own origin, and, in renouncing the nostalgia and desire to coincide, it establishes a language in the void of this temporal difference. In so doing, it prevents itself from an illusory identification with the non-self, which is now fully, though painfully, recognized as a non-self. ${ }^{27} p$

Heritage" is haunted by the narrator's recognition of himself as the poem's subject, a subject who must answer to an unfamiliar and unrecognizable self that responds to calls he can never hope to know or understand. This haunting enables the poem's allegorical structure, insofar as the epistemological journey that carries him away from the constructed symbols that constitute his knowledge of Africa cannot in fact lead him to another alternative; there is only distance, embodied in himself. For this narrator, then, Morrison's flooding also means suffering from what he cannot know yet also cannot forget:
so I lie, who always hear,
Though I cram against my ear
Both my thumbs, and keep them there,
Great drums throbbing through the air.
So I lie, whose fount of pride,
dear distress, and joy allied
Is my somber flesh and skin,
With the dark blood dammed within
Like great pulsing tides of wine
That, I fear, must burst the fine
Channels of the chafing net
Where they surge and foam and fret

(19-30)

"Heritage" ends where "The Negro Speaks of Rivers" begins. In this instance, however, the river is dammed.

\section{Flooding}

Although Cullen's poem focuses very clearly on the limits and dangers of the semiotic, it, in the end, also expresses the agony of a body that nonetheless threatens to attempt an impossible return. If we follow Kristeva, the presence-then-absence of the mother's body structures subjectivity, and thus our nature and will to participate in the symbolic - our very speech-flows and ebbs according to this loss. She refers to this as chora, antecedent to signification, felt as absence, and mediated by languageparticularly as such absence is intentionally reified in poetic language-flowing through the subject and advocating the reclamation of lost sites. I hear this echoed in 
Morrison's claim that “ $[\mathrm{w}]$ riters are like that: remembering where we were, what valley we ran through, what the banks were like, the light that was there and the route back to our original place... [A] rush of imagination is our 'flooding.' ${ }_{28}$ At the most basic level, thinking about memory vis-à-vis the semiotic offers a way of thinking about aspects of memory that often seem beyond interpretation and escape rational discussion yet are somehow always described. "Like water," Morrison concludes, "I remember where I was before I was 'straightened out.' ${ }^{\prime 29}$

In a poem entitled "Danse Africaine" (1922), Hughes uses the figure of the drum to shift the responsibility for remembering more fully onto the body, which now must only respond to a prompt. Overdetermined, the rhythmic beating of the tom-tom moves the post-Passage body in time, moves it in memory of, in lieu of, the time before the break:

\author{
And the tom-toms beat, \\ And the tom-toms beat, \\ And the low beating of the tom-toms \\ Stirs your blood
}

$(12-15)$

As long as the tom-toms beat, the post-Passage subject will respond to its rhythms. Unprovable, unreferenceable, and carried on the lowest [443] frequencies, such notions, or perhaps more precisely such feelings - such surgings, such foamings, and such frettings - offer insight into the ways something familiar might be produced out of something we are never sure to know. But what, as Cullen might wonder, is the place of agency in this? Where is the balance between thinking one knows and knowing one knows?

Helene Johnson, another Harlem Renaissance poet, offers a sophisticated middle space between Hughes's acquisitive enthusiasm and Cullen's haunted weariness. In a piece entitled "Poem," Johnson speaks to how any ambivalence one might feel about a site of memory need not necessarily be antithetical to finding value or usefulness therein. The poem's speaker is a girl in a club, watching a singer on stage in Harlem:

Little brown boy,

Slim, dark, big-eyed,

Crooning love songs to your banjo

Down at the Lafayette-

Gee, boy, I love the way you hold your head,

High sort of and a bit to one side,

Like a prince, a jazz prince. And I love

Your eyes flashing, and your hands,

And your patent-leathered feet,

And your shoulders jerking the jig-wa.

And I love your teeth flashing,

And the way your hair shines in the spotlight

Like it was the real stuff. ${ }^{30}$ 
There is obvious affection in her references to the performer as "[1]ittle" and "[s]lim" and "big-eyed," descriptions that might seem otherwise incongruous with his status as an entertainer at one of Harlem's most important night clubs. And it is indeed clear that, despite the quiet "[g]ee, boy" intimacy with which she describes him, he holds her too in his power:

\author{
Gee, brown boy, I loves you all over. \\ I'm glad I'm a jig. I'm glad I can \\ Understand your dancin' and your \\ Singin', and feel all the happiness \\ And joy and don't care in you. \\ $(14-18)$
}

The speaker's identity as a jig, which places her socially, racially, and sexually within a certain milieu, comes into being through her sense of understanding the brown boy's performance. On stage, he is visually [444] enlarged and vibrant, "flashing" and "jerking" and "shin[ing]." But, again, there is something slow and drawn-out in her description of him, and this slow-motion tempo creates a sense that the speaker might somehow know more about the boy on stage, in his presence, than the poem's reader ever could. Perhaps this is because even though the poem's imagery gives us one thing, a bright, fast, and vibrant jig-wa, the poem's speaker distinctly hears something else behind the visual, something moving on a different time:

Gee, boy, when you sing, I can close my eyes

And hear tom-toms just as plain.

(19-20)

"Tom-toms" - a new buzzword to the Harlem Renaissance, a newly enlarged frame of reference, a still-fresh site of memory that refers back to the "dancin" and the "[s]ingin" " and "the happiness." Does she hear the tom-tom in his voice? Or does she hear the tom-tom in her own listening?

Listen to me, will you, what do I know

About tom-toms? But I like the word, sort of,

Don't you? It belongs to us.

$(21-23)$

The speaker hesitates in the midst of her reverie. She knows that, despite the real pleasure she might experience in her feelings, there might also be something superficial, artificial, in hearing tom-toms behind his voice. But what matters is the ownership and sharing of the artifice, more so than the relative veracity of its significations. After this brief hesitation, the poem ends by echoing its own beginning, now even further collapsing the distance between the speaker and the boy on stage: 
Gee, boy, I love the way you hold your head, and the way you sing, and dance, And everything.

Say, I think you're wonderful. You're

Alright with me,

You are.

$(24-29)$

The distance is closing, but not completely. Much as the singer's hair shines in the spotlight only like "the real stuff," there will be no grand becoming or explosive transcendence. She does not become him and [445] he does not become anything more than who he already is, a boy with a banjo. "You're / Alright with me," is not even "I love you." But it is a real affection. And what matters here is the graciousness of the final "You are," all anyone needs to give and receive in order to live life more fully, the final purpose of any site of memory.

\section{Notes}

1. Melvin Dixon, "The Black Writer's Use of Memory," in History and Memory in African-American Culture, ed. Robert O’Meally and Geneviève Fabre (New York: Oxford Univ. Press, 1994), 21.

2. Dixon, 20.

3. Pierre Nora, “Between Memory and History: Les Lieux De Mémoire," Representations, no. 26 (1989): 7.

4. See Nora, 7.

5. Karla F. C. Holloway, Passed On: African American Mourning Stories: A Memorial (Durham: Duke Univ. Press, 2002$), 6$.

6. Olaudah Equiano, "The Interesting Narrative of the Life of Olaudah Equiano," in Black Atlantic Writers of the Eighteenth Century, ed. Adam Potkay and Sandra Burr (New York: St. Martin’s Press, 1995), 185.

7. Quobna Ottoba Cugoano, “Thoughts and Sentiments on the Evil and Wicked Traffic of the Commerce of the Human Species," in Black Atlantic Writers, 134.

8. Equiano, 186.

9. Equiano, 186.

10. See Langston Hughes, The Big Sea (New York: Thunder's Mouth Press, 1986), 50.

11. Hughes, Big Sea, 54, 55. I find it interesting that Hughes's nostalgia is not unlike Nora's, who makes repeated references to milieux de mémoire as environments in which one would experience living in "the warmth of tradition" and "the silence of custom" (7). Both men at times hearken to a belief in the embedded authenticity of a pre-modern, premigration world. For Nora, this world in which living is real and meaningful is located squarely amongst the rural class; for Hughes, it is with Southerners, particularly they who would become the newly migrated working-class people whom he both envied and admired.

12. Hughes, Big Sea, 118 .

13. The difference, of course, is that whereas the Middle Passage signifies a passage between continents, being "sold down the river" signifies an interiorized second (and third and fourth...) passage that happens entirely on American soil. Regardless, the journey remains constitutive of post-Passage subjectivity. 
14. Hughes, "The Negro Speaks of Rivers," in The Collected Poems of Langston Hughes, ed. Arnold Rampersad (New York: Knopf, 1994), lines 1-3. All subsequent Hughes poems are from this edition and will be cited parenthetically by line number. [446]

15. Julia Kristeva, Revolution in Poetic Language, trans. Margaret Walker (New York: Columbia Univ. Press, 1984$), 57$.

16. Kristeva, 48 .

17. Kristeva, 58.

18. Hughes, Big Sea, 118.

19. I am not suggesting here that Pey speaks as an authentic African who actually holds the power to determine Hughes's racial membership. Rather, what I am interested in is the validation Hughes wants from Pey, and the way that Pey even if it could be read as a misrecognition on his part-refuses to give it.

20. Hortense J. Spillers, “Mama's Baby, Papa's Maybe: An American Grammar Book,” Diacritics 17.2 (1987): 72.

21. Rampersad, The Life of Langston Hughes, 2 vols. (New York: Oxford Univ. Press, 1986), 1:78. For Hughes, the impossibility of identification with a racially homogeneous origin would become a pervasive concern throughout his career; see Rampersad, 1:82.

22. Dixon, 24 .

23. Countee Cullen, "Heritage," in My Soul's High Song: The Collected Writings of Countee Cullen, ed. and intro. Gerald Early (New York: Doubleday, 1991), lines 31-37. Hereafter cited parenthetically by line number.

24. Dixon, 24.

25. Early, introduction to My Soul's High Song, 59-60.

26. Toni Morrison, “The Site of Memory," in Inventing Truth: The Art and Craft of Memoir, ed. William Zinsser (Boston: Houghton Mifflin, 1987), 119.

27. Paul de Man, "The Rhetoric of Temporality," in Blindness and Insight: Essays in the Rhetoric of Contemporary Criticism (Minneapolis: Univ. of Minnesota Press, 1983), 207.

28. Morrison, 119.

29. Morrison, 120.

30. Helene Johnson, "Poem," in Shadowed Dreams: Women's Poetry of the Harlem Renaissance, ed. Maureen Honey (New Brunswick: Rutgers Univ. Press, 1989), lines 1-13. Hereafter cited parenthetically by line number. [447]

Copyright (C 2007 The Johns Hopkins University Press 